\title{
Heat from Dust
}

Utilization of Low Grade and Waste Fuels

By Charles L. Wright

Fuel Engineer in Charge of the Fuel Briquetting Investigations of the United States Bureau of Mines

THE natural resources of our country have been conTidered so inexhaustible that it is only very recently that the attention of the public has been direct ed to the enormous amount of material wastcd in our various industries; and it is to be hoped that the socalled conservation movement may continue until we as a nation, reach the industrial effiency that has been attained by the older countries-Great Britain, Germany, France, and others. Furthermore, it is to be hoped that we may not wait as these countries have until the most valuable resources are gone for ever, before putting this conservation process into effect.

According to the United States Geological Survey's report, $459,209,073$ short tons of coal were produced in the United States in the year 1909, of which 83,000 , 000 short tons were anthracite coal from Pennsylvania.

In the eastern section of the United States, where most of the coal is mined and used, the price of the better grades of coal is steadily increasing. It is now estimated that the maximum tonnage of anthracite possible to produce annually has nearly been reached. If this is true the price of this popular domestic fuel will in a few years place it out of reach of all but the wealthy for a domestic fuel. Then people must look for some other kinds of fuel which will be suitable for household use.

On the other hand, the demand for industrial fuel is increasing more rapidly than the development of coal mining, and therefore manufacturers are already on the lookout for a more economical fuel in order to re duce the cost of production, or at least to keep it from being increased. Our industrial prestige is due in no small measure to our having had great natural fuel resources; and as competition becomes keener with other nations and the price of our fuels is at the same time advancing, we must make use of the cheaper fuels and fuel wastes in order to hold our present position. The purpose of this article is to discuss in a general way the various materials suitable for fuel which are now wasted or considered of small value, and therefore disposed of at a low price; and to discuss the ways that such wastes may be utilized to better advantage.

The following fuel wastes and low grade fuels ar considered in this article: Bituminous slack, anthracite culm, coke breeze, sawdust and wood waste, lignite coal and peat.

Bituminous Slack. Most companies mining bitumin ous coal screen all or part of their product before shipping, to remove the dust and finer pieces of coal which is called "slack." The size of the opening in the screen used varies with different operations, but the size of opening most commonly used is $3 / 4$ of an inch; so generally speaking slack is that portion of the mined coal which passes through the screen with $3 / 4$ inch openings.

As high as 50 per cent of the coal mined is in the form of slack. Formerly there was no market for this slack, and it was dumped in piles near the mine and accumulated from year to year. These piles of siack were sometimes set on fire to get rid of them, and would smolder away for years.

At the present time there is in certain parts of this country, for example the eastern and middle States, a market for this slack coal for use in special furnaces, as an industrial fuel. There is not, however a market large enough for all the slack produced, and in many places, if it is sold at all, it is sold at a price which is less than the cost of producing it, the profit of the business being made from the sale of the larger sizes. Around Pittsburg slack may be had in carload lots for 85 cents to $\$ 1$ a ton delivered at the plant. In other States it brings 15 to 50 cents per ton, loaded on cars at the mine. How this waste by means of briquetting and the gas-producer can be converted into desirable household fuel and power will be described further on in this article.

Anthracite Culm. Anthracite culm is similar to bituminous slack in that it composes the smaller sizes of anthracite coal. As with bituminous coal these finer sizes were formerly a waste material, and in the anthracite fields of Pennsylvania to-day there are great hills of this culm which have accumulated for many tage over bituminous slack that it produces practically (Continued on paye 456.)

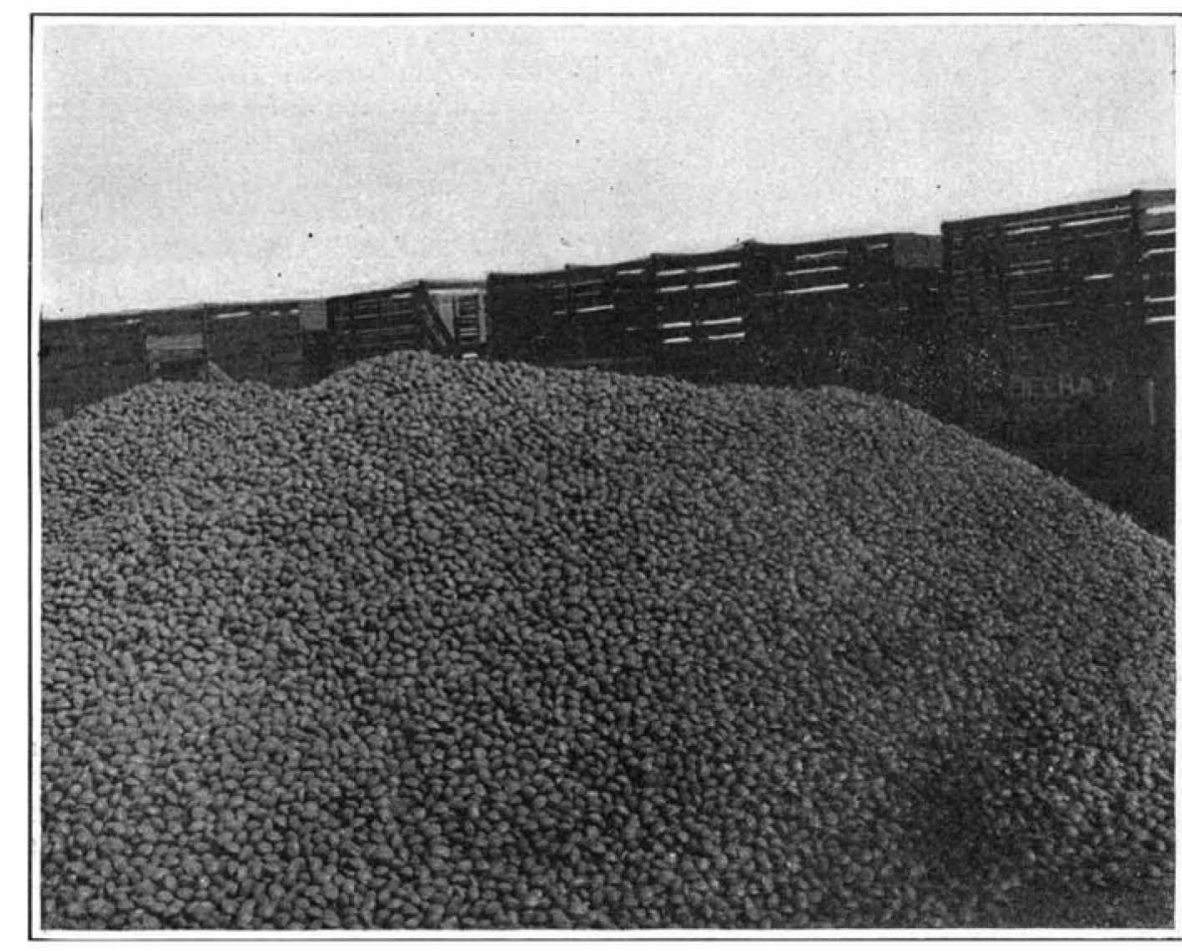

A pile of clam-shaped fuel briquets.

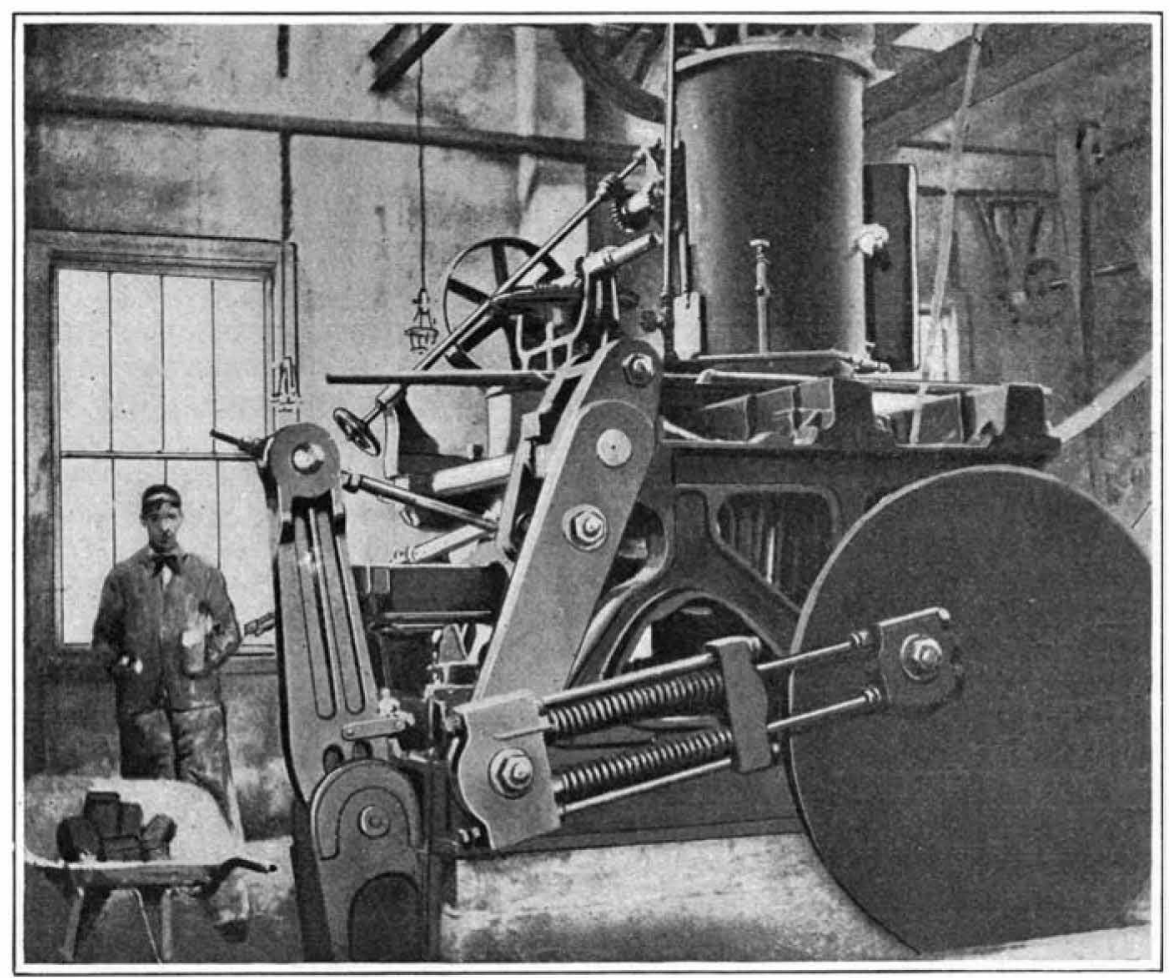

Briquetting machine of English make. Note the briquets in the wheel-barrow.

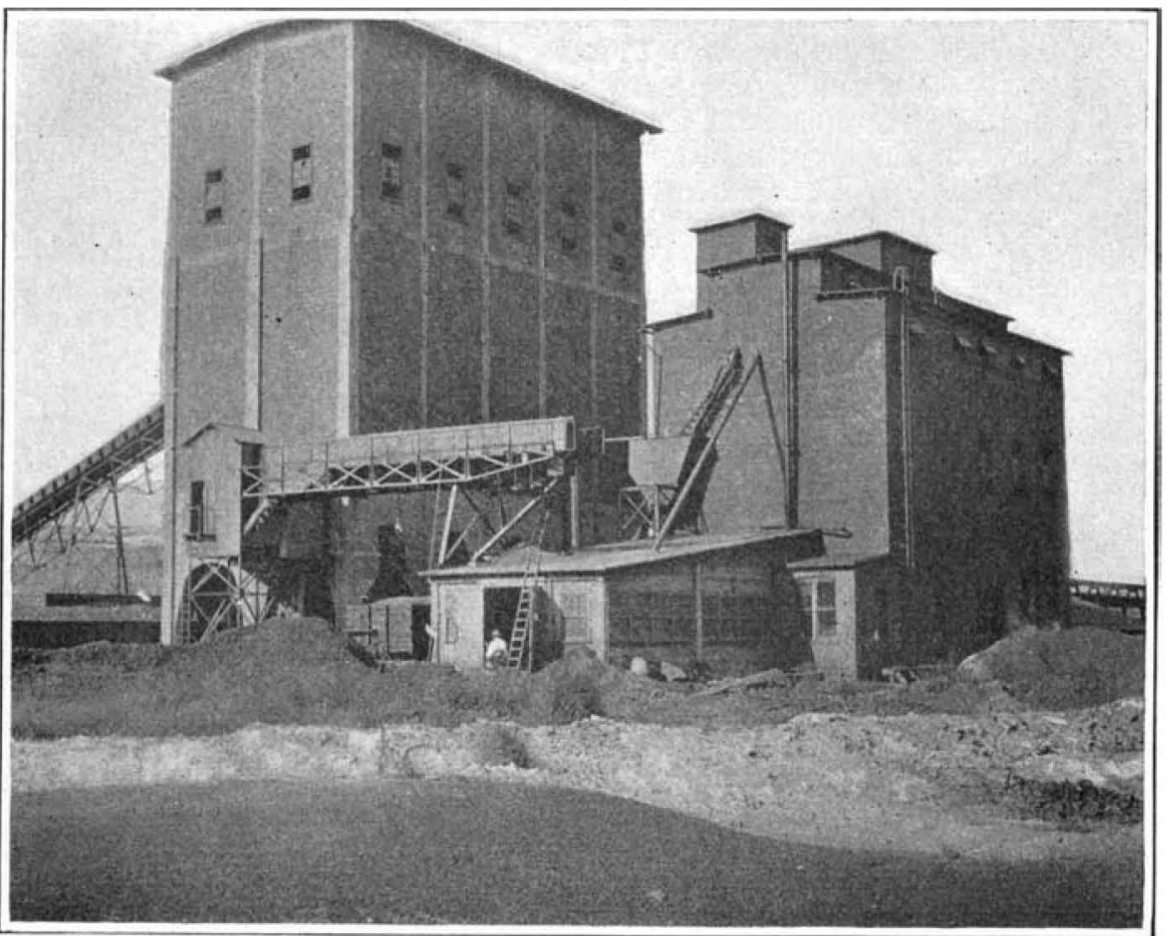

A typical fuel-briquetting plant.

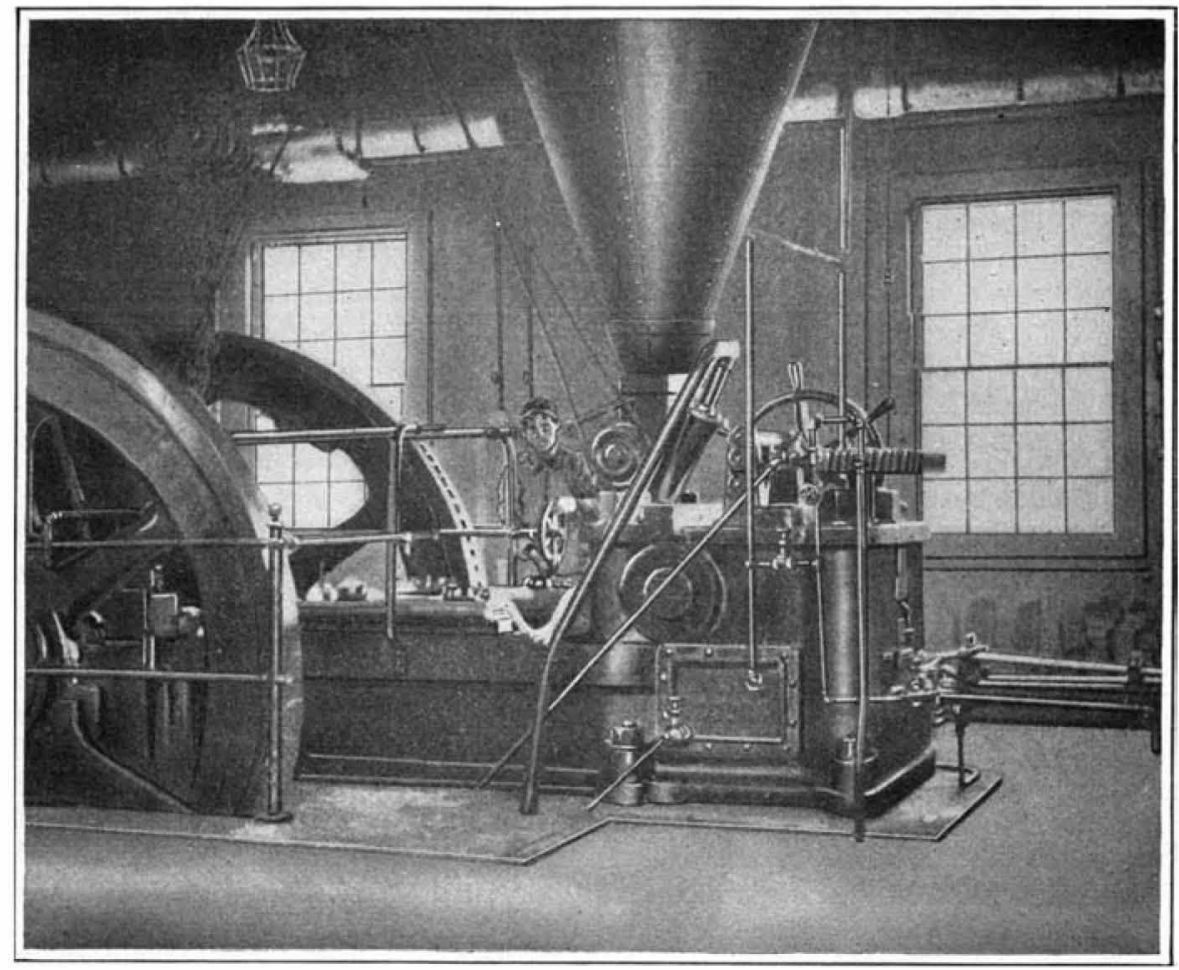

A German type of briquetting machine used by the United States Bureau of Mines 


\section{It Works Like a Kodak.

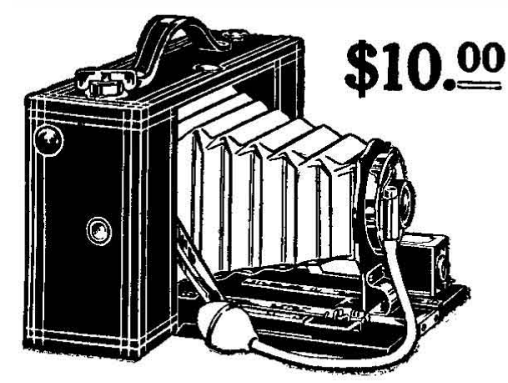 \\ No. 3A Folding BROWNIE}

Pictures Post Card Size.

The first Brownie made $2 \mathrm{~T} / 4 \times 2 \mathrm{~T} / \mathrm{f}$ pictures and sold for a dollar.

It was made so well that other and bigger Brownies simply had to follow. They are made in the Kodak factories under Kodak superintendence by Kodak workmen. Habit with these people means honest workmanship. That's why the Brownie, a low priced camera, has been and is a success.

The No. 3A Folding is the largest of the Brownie family, taking pictures of
post card size ( $31 \%$ × $5^{5 \% 2}$ inches). Like the other Brownies it loads in daylight, using Kodak film cartridges. It is a camera in every detail. It has our shots and time exposures, with bulb release, automatic focusing lock, two
tripod sockets and reversible finder. Price, with Meniscus Achro-

mo., with Rapid Rectilinear lens, $\mathbf{\text { I2.00 }}$

Ask your dealer or write us for complete
catalogue of Kodak and Brownie cameras.

EASTMAN KODAK CO. ROCHESTER, N. Y.. The Kodak Citto
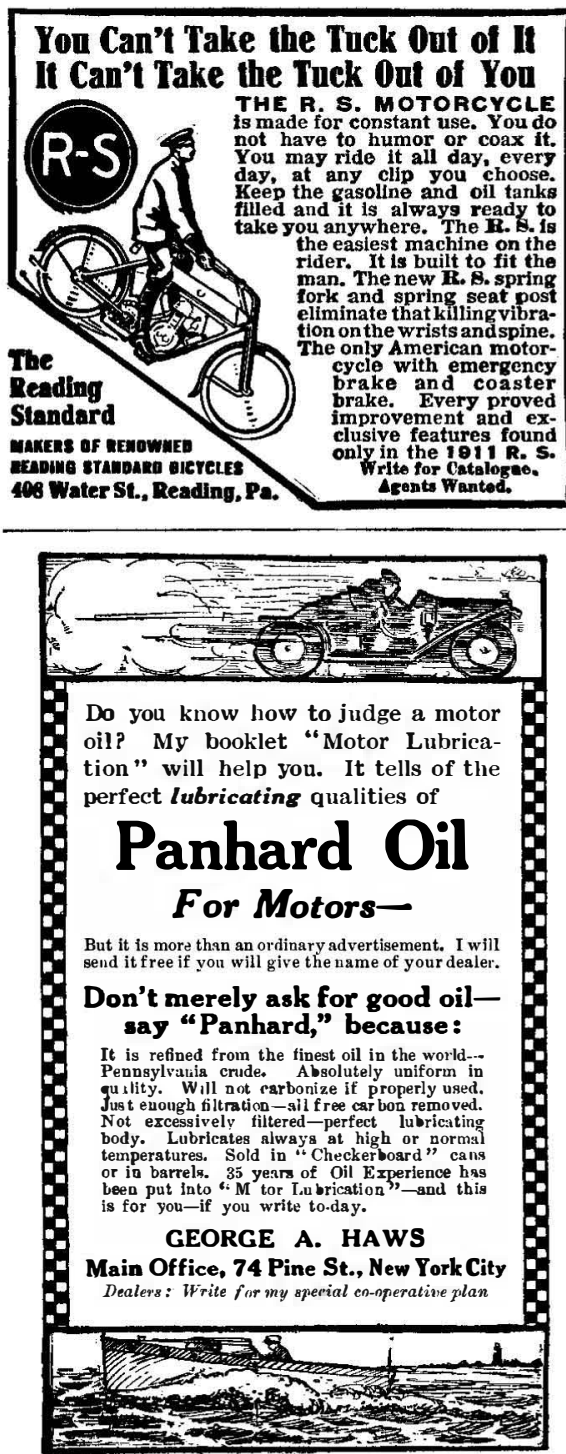

\section{Heat from Dust}

(Continued from pase 44t)

no smoke in burning, and therefore large amounts of it are now being removed
from the banks, where it has been stored for years, subjected to a washing process if necessary and shipped to the
larger cities of New York State and New England, where it is sold as a fuel for heating office buildings and producing power in plants located in cíties having power in plants located in cittes having largest user of this culm.

This anthracite culm makes excellent briquets and gas-producer fuel, as will be shown presently.

product of the coke or gas industries. In the preparation of illuminating gas, the coke resulting from the distillation of
the coal when removed from retorts is in the form of large and small pieces and dust. This dust and smaller sizes called coke breeze.

In the manufacture of coke, both by the bee hive oven and by-product
methods, coke breeze is also obtained in large quantities. Methods of utilizing are described further on in this article. Sawdust and Wood Waste. One of the most wasteful of our industries is the
wood industry. Mr. George B. Frankwood industry. Mr. George B. Frank-
forter states in a recent article on "Wood forter states in a recent article on "Wood
Waste and Its Utilization" that the bes that model mills can do at the present time in the logging and milling part of the industry is to save a scant 40 per lumber, laths and shingles. Fifteen year ago the average was probably only 30 per cent. The average, now, is about 35 per cent lumber and 65 per cent waste. Th sawdust. From 5 to 15 per cent of the logs sawed go into slabs. About 20 per most economical lumber mills in the country, at Marshfield, Oregon, saw on in a year, or approximately 150,000 ton of lumber. On the basis of 65 per cent waste, this one mill alone produces anwually 225,000 tons of wood waste, an this waste is burned either on the ground where the trees were cut or in waste
burning furnaces at the mill. If one mill, and that the most economical, pro duces annually 225,000 tons of waste this country must be enormous. This wood waste can be utilized in
several ways, some of which will be mentioned. Lignite. Lignite is a variety of fuel
between peat and bituminous coal in quality. One form of lignite is called brown coal in Germany from its characteristic color. In this country it is tiste
custom to speak of two kinds of lignite. viz.; lignite and black lignite.

There are immense deposits of lignit coal in the western and southern states,
the most important deposits being found in Texas, North Dakota, Colorado, Montana and California. These deposits
vary in thickness from a few inches to vary in thickness from a few inches to
over thirty feet. This fuel contains high percentage of water, American lignites having as high as 42 per cent of
moisture in them when fresh from the moisture in them when resh from the
mine. This high moisture content decreases the heat value of the fuel, and as it is non-caking, special furnaces are re
quired to burn the raw lignite properly. quired to burn the raw lignite properly.
Lignite cannot be stored in the open in large piles on account of the slackening down that takes place when it is exposed to the weather for only a few weeks.
Spontaneous combustion also occur more easily in piles of this fuel than with bituminous coal.

Peat. Peat is the lowest grade of fuel It is the partially decomposed remains of moss, and other similar plants, which are found in wet marshy places. Its high moisture content (sometimes as extensive use as a fuel, as all attempts to dry it artificially on a large scale have not been profitable, as the cost of handling large amounts of raw materia and supplying heat to dry it is prohib
tive. Numerous experiments in this country
ive. with much success up to the present in selling all that can be made at a profit time, but possibly in a few years the of not less than one dollar a ton. I
high price of other fuel will lead to
sacked and peddled at retail $\$ 6$ to $\$ 8$ per

Combustion of the fuel in the lower par nd this is partially reduced to carbon onoxide in passing through the in The steam is broken up into hydro n and oxygen. The hydrogen and carmonoxide are combustible gases and oxide they form producer-gas which s comparatively low heat value. produces power at a much the steam boiler and steam engine. producers are extensively used as a means of generating gas for power purDoses from lignite and waste fuel mat
erials. In the interior of a scrub growth of wood for gas-procer fuel with satisfactory results. the West a develop in those parts posits of lignite are to be found, we ay look for a rapid increase in the umber of producer-gas plants using and as these parts of the country become ore thickly populated by people en aged in agriculture as well as in in astrial pursuits, there will be a de
and for lignite briquets for domestic

Bituminous slack, anthracite culm, wood waste, lignite and even peat, if the excellent efficiency in the gas-producer. Coke breeze also gives good results as aw state furnishes an excellent prothe gas produced from the best grades of bituminous coal. This improvement the lignite intount of moisture found in Peat is a good gas-producer fuel if air dried before use so that it contains less an 40 per cent of moisture.

Briquetted Fuel. The process of iquetting fuel, although not very well best method of converting a low grade izing the waste from mining high grad uel. The briquetting process is This briquetting process has been suc cessfully used by European countries for In the year 1908 the world production briquetted fuel was $28,600,000$ shor tons of which Germany produced 20,900, In the same year the United States proof about $\$ 3.50$ per ton. In 1909 the tons, an increase of $54 \mathrm{per}$ cent in quan-
tity and valued at $\$ 452,697$, or $\$ 3.25$ per United States. There were sixteen plants in this country which produced fuel plants were only experimental, about onethird of them are built on a practica basis and are apparently meeting with he advantages of briquetted fuel, it is

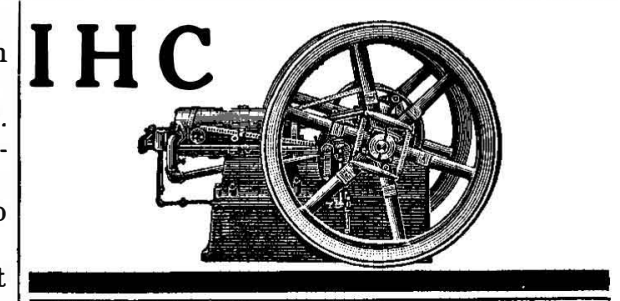

For Every Power Need

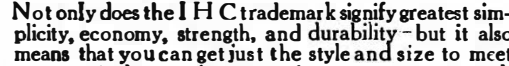

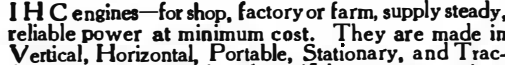

tion strles-in many sizes 1 to 45 -horse-power - air or
water conled

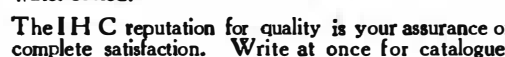

INTERNATIONAL HARVESTER COMPANY OF AMERICA

CHICAGO U S A This producer-gas when used in a gas In those European countries where the here coal is scarce, mining companies is due in large measure to decomposition material into solid blocks called briquets. duced only 90,358 short tons valued at
the plant at $\$ 323,057$, or an average price United States produced 139,661 short ton, so that it is evident the industry is

When the public is once familiar with
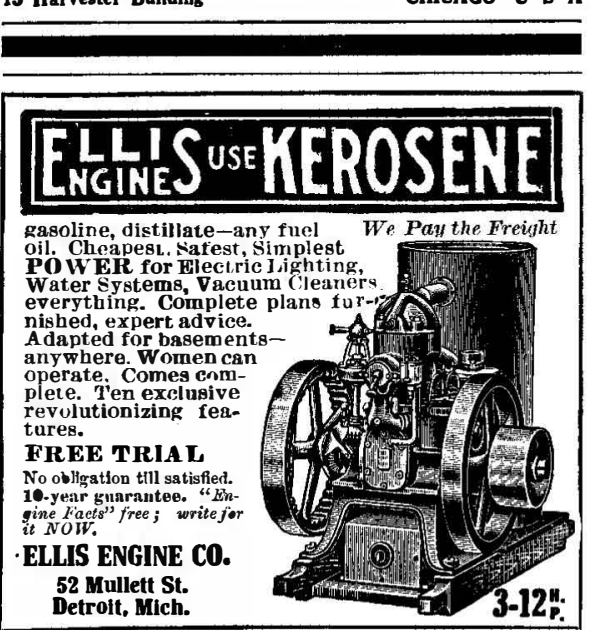

JA GER Marine

4-Cycle Engines

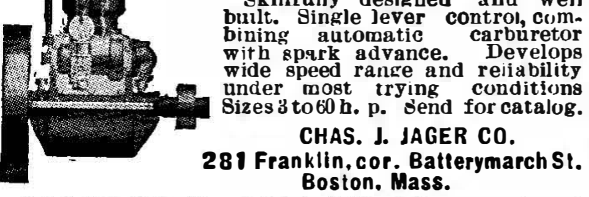

281 Franklis. cor. Battering
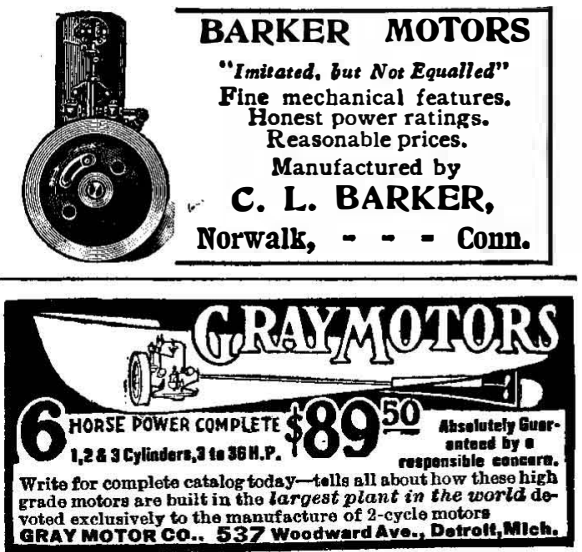

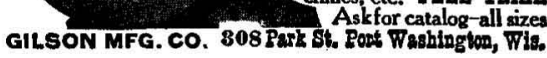

PALMER MOTORE AND
2 AND 4 CrCLE LAUNCHES

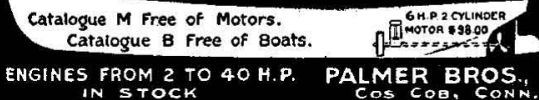

How Manufacturers Can Increase Their BUSINESS

Read Carefully, Every Week, the Classified Advertising Column $\overline{\text { SCIENTIFIC AMERICAN }^{\text {IN }}}$ Some week you will be likely to find an inquiry for something that you manufacture or deal in. A


WATCH IT CAREFULLY 


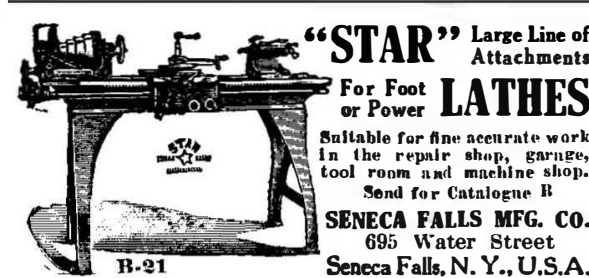

THE SEBASTIAN 15-INCH ENGINE LATHE Automobile Builders, Garages, Repair PRA PRE


LATHES FOOT or POWER, 9 to 13-inch $\$ 75.00$

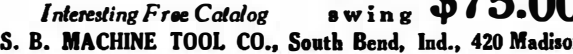

This GRINDER

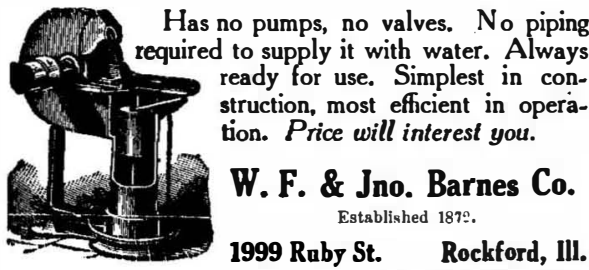

HALF DOLLAR TAP WRENCH

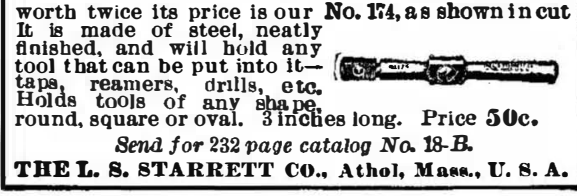

Practical lead Burner \& Chemical Plumber Builder of all kinds of Lead A pparatuses, tanks line
and lead fittings made to order. Thurty years' ex perience (advice rree).
JOHN VOLLER,
5 Westerly St., Boston, Ma

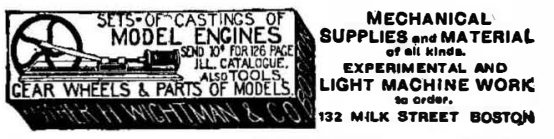

Complete lists of manufacturers in all lines supplied at short notice at moderate compiled to order at various prices.

MUNN \& CO. Inc. PUBLISHERS Lid Department Box 773 New York

RUBBER $\begin{gathered}\text { Expert Manufacturers } \\ \text { Fine Jobbing Work }\end{gathered}$ PARKER, STEARNS \& CO., 288-290 Sheffield, Ave., Brooklyn, N.

Patented Articles and Metal Specialties MANUFACTURED BY CONTRACT

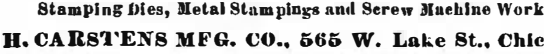
GPACHINES Corliss Engines, Brewers Tho VILTER MFG. CO.

899 Clinton Street, Milwaukee, Wis. THE BEST EQUfiPPED SHOP
For Mechanical and Electrical Manufacturing Repairs, Experimental Devices

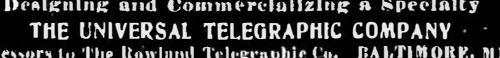

Models \& Experimental Work INVENTIONS DEVELOPED

E.V. BAILLARD CO., 24 Frankfort St., N.Y.

\section{NOVELTIES \& PATENTED ARTICLES}

Manufacturers of Metal Specialties, Stampings, Dies and Tools. Thirty Power Presses at your service.
Hoeft \& Company, Inc. CHICAGo,
U. S. A.

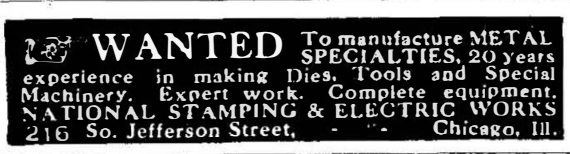

MANUFACTURERS, ADDITIONAL CAPITAL We are in communication with cities and town
having frst-class manufacturing and shipping factlitives
that will grant concessions, remit taxes and give botn factory or en desire to reve-organize or re-jocate you
if so communicate with us. A. F. DOW COMPANY g2 STATE STREET COMMISSIONERS

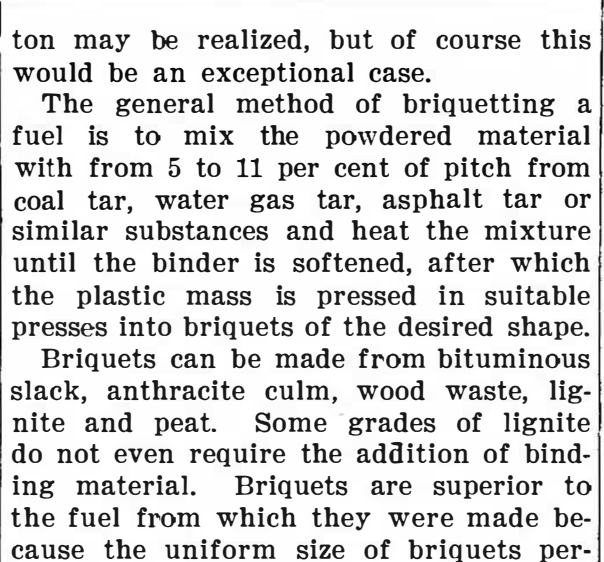

ause the uniform size of briquets perthey withstand the effects of weathering onger; if properly made they burn with there is less loss by breakage in trans-
the portation and the danger of spontaneous combustion is eliminated when fuel is Briquetted fuel is now on sale in New York city and vicinity; Detroit, Michigan; Kansas City, Missouri; Indianapolis, Indiana; St. Louis, Missouri;
perior, Wisconsin, and other cities. perior, Wisconsin, and other cities. value, has been to a large extent wasted
and many attempts have been made to briquet it, but up to the present time
with small success, owing to the abrasive with small success, owing to the abrasive
action of the breeze which acts very much like carborundum and wears the dies and working parts of the machinery
quickly. Attempts to briquet it are being quickly. Attempts to briquet it are being continued, however, and it is to be hoped
that ultimately this can be successfully one.

Bituminous slack and anthracite culm practically all of the fuel briquetting plants of the country are at the present Sawdust is briquetted by several firms ust briquets, a household fuel. Sawgnited as wood, burn much more slowly so highly in the making. This is an advantage as the fire does not need replenshing so often.

As stated above, some varieties of ligtion of binding material. To do this,
tion however, a very high pressure is re-
quired. Those lignites which require quired. Those lignites which require wand the weather better than those made without binder.

In Germany, brown coal briquets have been used for the last thirty years as a
household fuel, and in the year 1908 $15,700,000$ short tons of these brown coal
briquets were produced in that country. North Dakota is now carrying on invest gations looking to the utilization of th
lignite deposits within the borders Peat cannot be profitably briquetted by the same method used for coals and lig. nite, but considerable success has been met with in converting peat into fuel peat and squeezing the wet mass through the gradually narrowing orifice of a sointo suitable lengths and then stacking these pieces to dry in the open air or in
low sheds with roofs but no sides. In parts of Germany and Sweden the man has attained considerable importance. ment has carried on extensive investiga ment has carried on extensive investigaproducer, coking, and other qualities of of these valuable investigations have been published in bulletins of the United States Geological Survey and the Bureau
of Mines. These bulletins may be obtained without charge by application to the director of the Bureau of Mines,
Washington, D. C.
Behavior of Iron in Concrete-AccordBehavior of Iron in Concrete. - Accord-
ing to The Engineer, a reinforced coning to The Engineer, a reinforced con-
crete slab roof, built in Paris in 1852, in which was imbedded some small $31 / 4^{-}$
inch I beams, has shown a perfect presinch I beams, has shown a perfect pres-
ervation of the iron. Thirteen years ago
a portion of the concrete was removed, a portion of the concrete was removed,
and the iron found to be in perfect condition. Recently a similar examination was made, which
any deterioration.

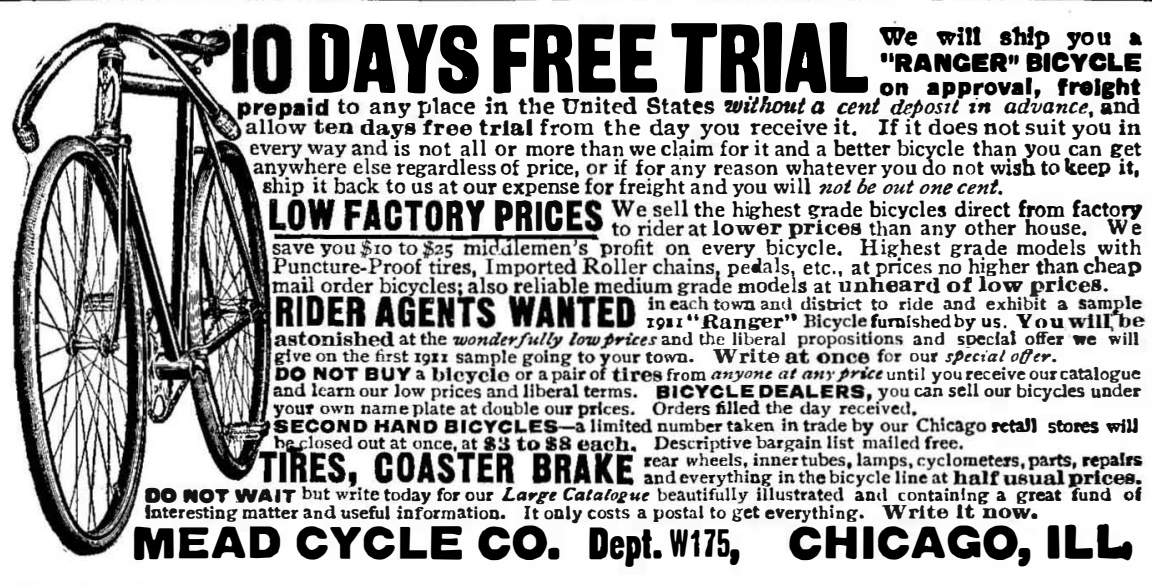

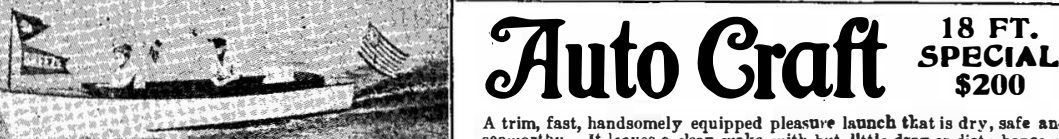

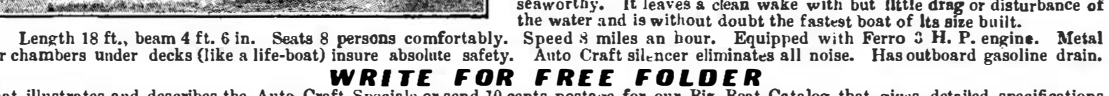

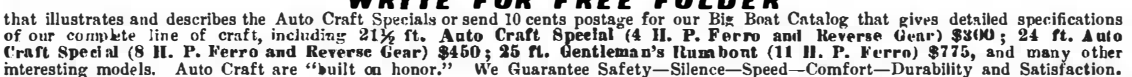
THE CLEVELAND AUTO BOAT MFC. CO., 1047 River Ave., N. W., Cleveland, Olılo, U.S.A.
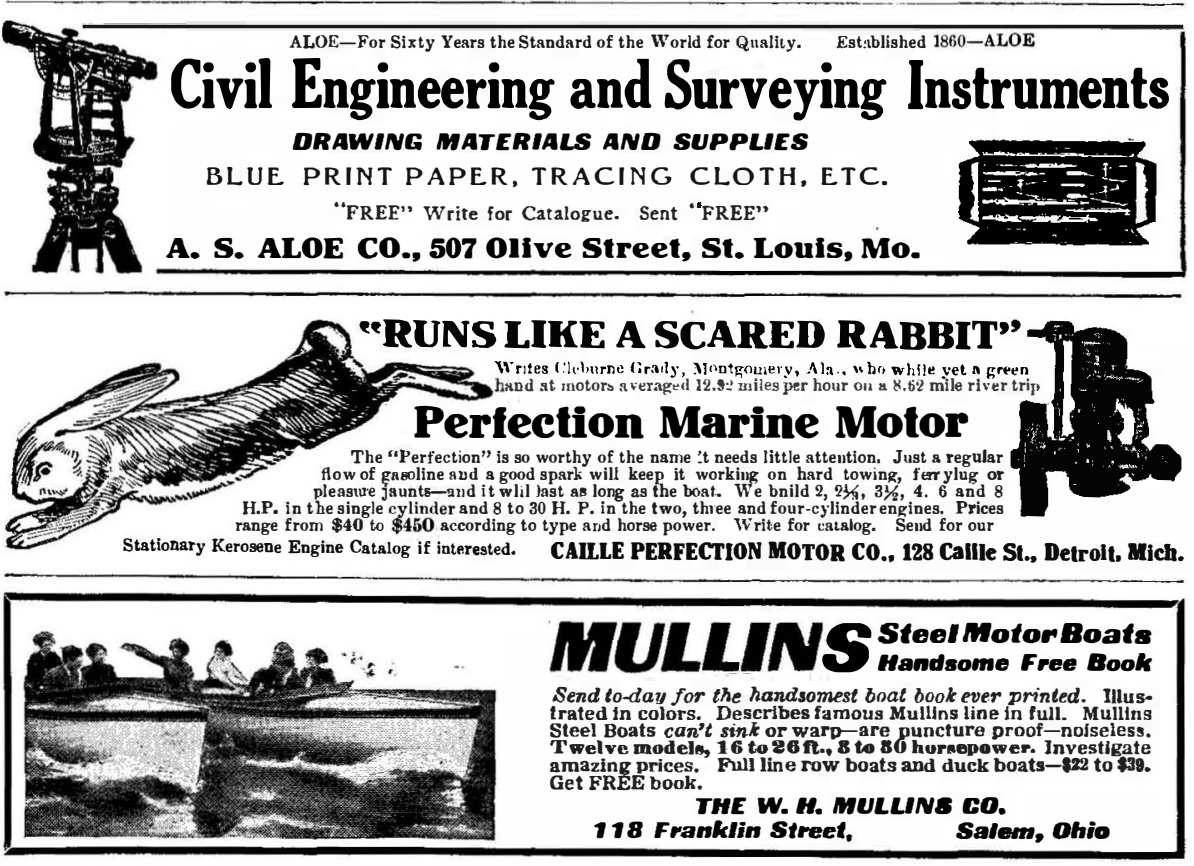

I A HOME-MADE 100-MILE WIRELESS TELEGRAPH SET Read Scientific American Supplement 1605 for a thorough, clear description, by A. Frederick Collins. Numerous adequate dia-
grams accompany the text. Price, 10 cents, by mail. Order from your newsdealer or $\mathscr{J}$ unn $\mathcal{L}$ Co., Inc., 361 Broadway, N.Y.

New York Electrical School

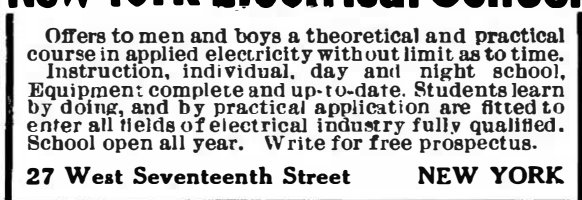

\section{AIRCRAFT}

The World's Great Magazine of Aerial Flight

A Collection of Issues Makes a Complete Aeronautical Encyclopedia

Edited by Experts under the General Supervision
of Alfred W. Lawson

Accurate Construction Work a Special F
Complete Records and Statistics New Flyers Described

Illustrations from every Quarter of the Globe

Recent numbers contain exclusive articles
by such famous men as: Clément Ader, Louis Paulhan, Robert Esnault-Petterie, Louis
Bleriot, George F. Campbell Wood, Denys P. A. Lawrence Rotch, General James Allen,
Glenn Curtiss, Chas. K. Hamilton, Henry A
Wise Wood, Major S. Reber, Israel Ludlow,

\section{SUBSCRIPTION RATES}

$\$ 1.50$ per year $\$ 1.00$ eight month ck numbers 25c per copy, except $A$ pril which $\$ 1.00$ a cops, and December which is
$\$ 1.25$ per copy. Bound books in

cloth of the first twe

THE LAWSON PUBLISH:NG COMPANY 37-39 E. 28th St., New York, U. S. A.
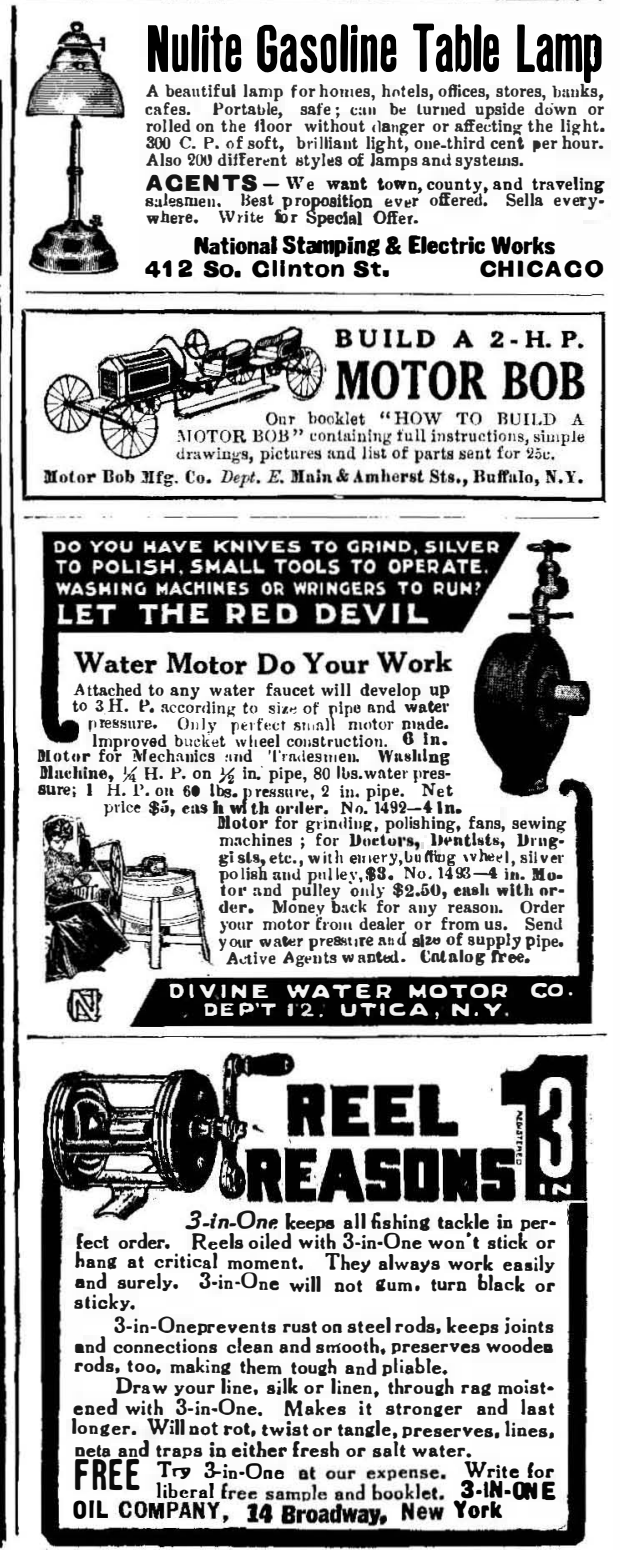